\section{'Gestation, Equality and Freedom: Ectogenesis as a Political Perspective' response to commentaries}

\author{
Giulia Cavaliere
}

Let me begin by thanking the Journal of Medical Ethics editors and the four commentators for taking time to read, reflect and offer thoughtful comments on my paper. The issues they raise warrant careful attention. Regrettably, I am only able to address some of their key concerns due to space constraints. In my paper, 'Gestation, Equality and Freedom: Ectogenesis as a Political Perspective', I outline two sets of critiques of liberal defences of ectogenesis and contend that these defences are limited in their reach and scope. Building on Federici's, ${ }^{1}$ and Dalla Costa's and James' ${ }^{2}$ readings of the of the international feminist campaign 'Wages for Housework', I argue that the value of ectogenesis is to similarly advance a political perspective and a provocation. Framing ectogenesis in these terms enables to critically engage with the physical and social burdens of pregnancy, childbirth and childrearing, which all too often are borne by women. It also allows to demand for better medical and social services for mothers and women more generally, as well as better working and living conditions for these and other disadvantaged groups.

Lisa Campo-Engelstein thoughtfully broadens my reading of liberal defences of ectogenesis and contextualises them within the history of 'reproductive advancements and technologies'. 3 She illustrates that claims concerning increased freedom and equality are not unique to ectogenesis. Using egg freezing as a case study, CampoEngelstein argues that 'medicine is not the best tool to 'cure' oppressive power systems'. ${ }^{3}$ Her perspective follows an important tradition in feminist literature that casts a sceptical gaze towards using technical means to 'fix' social problems. While I share her concerns, I have a more favourable view on using technologies to serve liberating ends. Technologies have been and can be instruments of liberation,

Medical School, Lancaster University, Lancaster LA1 4YW, UK

Correspondence to Dr Giulia Cavaliere, Global Health and Social Medicine, King's College London, London WC2R 2LS, UK; g.cavaliere@lancaster.ac.uk if handled with care and with attention to the social circumstances in which they come into being.

In her commentary, Claire Horner disputes whether ectogenesis has any value at all, even of the kind that I am proposing. She argues that (1) critiques of ectogenesis do not give guidance regarding how to change unjust states of affairs and (2) the focus should not be on pregnancy but on the lack of 'political and social support for all who parent'. ${ }^{4}$ According to Horner, ectogenesis' value is 'limited even in its ability to advance this political perspective'. 'My reading of Horner's concerns is that they are of eminently political nature. The starting question of a debate on ectogenesis that seeks to further certain political ends should be what, if anything, can guarantee 'political and social support for all who parent'. Moreover, the answer to a strategic question should be whatever can, within certain limits, advance such political agenda. In this respect, there is a value in ectogenesis for it can advance a political project. One that-following Anne Phillips-considers equality as first of all 'a claim and commitment: not as the outcome of an argument, nor as the effect of sentimental education'.

Elizabeth Chloe Romanis's comments hinge on two issues: first, laws governing reproduction need be reformed. Such reform is necessary to prevent technological developments from furthering mechanisms of control over women's bodies. Second, she argues, while my critiques of liberal defences of ectogenesis are nominally correct, they should be focused on partial rather than full ectogenesis. I share her view on the need for legal reforms and see her concern as part of broader calls for changing the social milieu surrounding technological developments, which often hinders rather than promotes women's freedom and equality. Regarding the focus of the debate, Romanis and I advance compatible rather than mutually exclusive perspectives. The focus should be on both partial and full ectogeneses, regardless of urgency-motivated views. Both practices are worth discussing and raise specific ethical and political challenges that need to be addressed. My only reservation pertains to her view on the need to 'prevent political capture of the technology'. ${ }^{6}$ Romanis fears this development as '[h]istorically, technology has been politically captured to afford increased legitimacy for measures that subject pregnant people to greater control'. ${ }^{6}$ While this is broadly accurate, my reaction-and the perspective that I advance-goes in another direction, that of co-opting technological developments to serve liberating political projects.

It is maybe for this political co-opting that I earned the title of 'radical' in Glenn Cohen's commentary. Cohen advances three critiques to my paper. He argues that it (1) undercounts the potential benefits of ectogenesis, (2) sets the bar too high for the technology's permissibility and (3) de-emphasises risks concerning women's abortion rights ${ }^{7}$. Regarding the first critique, Cohen is right: ectogenesis-as other reproductive technologies-is likely to benefit groups whose freedom and equality in procreative matters are significantly curtailed. This is an important benefit and, other things being equal, a prima facie reason to support the development of this practice. Cohen also correctly points out that ectogenesis might pose risks to women's abortion rights. Abortion rights-and the rights of groups who have been systematically discriminated in procreation-warrant attention. I did not address these issues in my paper, as its scope was limited to discussions of liberal defences of ectogenesis, which often revolve around women. Regarding the second critique, Cohen correctly points out that 'the Perfect cannot be the enemy of the Good', and I do share his pragmatism. What is missing in his critique is an appreciation of the prioritarian nature of my arguments. Ectogenesis will likely benefit some women and increase their equality and freedom. However, it will increase the equality and freedom of those who do not need such increase the most. Moreover, I doubt that no one will be made worse off, as he claims. Women belonging to disadvantaged groups-who can come to be deemed 'substandard gestators' might be harmed by the development of ectogenesis. Whether greater control will be exercised on these women after the introduction of ectogenesis is an empirical question, but it is one that the history of control over women's reproductive bodies does not let us be overly optimistic about.

Twitter Giulia Cavaliere @giuli_cavaliere 
Funding The authors have not declared a specific grant for this research from any funding agency in the public, commercial or not-for-profit sectors.

Competing interests None declared.

Patient consent for publication Not required.

Provenance and peer review Not commissioned; internally peer reviewed.

(c) Author(s) (or their employer(s)) 2020. No commercial re-use. See rights and permissions. Published by BMJ.

\section{(A) Check for updates}

To cite Cavaliere G. J Med Ethics Epub ahead of print: [please include Day Month Year]. doi:10.1136/ medethics-2020-106099

Received 27 January 2020 Accepted 27 January 2020

\section{(P) Linked}

- http://dx.doi.org/10.1136/medethics-2019-105691

- http://dx.doi.org/10.1136/medethics-2019-105959

- http://dx.doi.org/10.1136/medethics-2019-105981

- http://dx.doi.org/10.1136/medethics-2019-105958

- http://dx.doi.org/10.1136/medethics-2019-105968

J Med Ethics 2020;0:1-2.

doi:10.1136/medethics-2020-106099

\section{ORCID iD}

Giulia Cavaliere http://orcid.org/0000-0001-8703-1499

\section{REFERENCES}

1 Federici S. Wages against housework. In: The politics of housework. Cheltenham, UK: New Clarion, 1995: 187-94.
2 Dalla Costa M, James S. The power of women and the subversion of the community. Bristol, UK: Falling Wall Press, 1975.

3 Campo-Engelstein L. Reproductive technologies are not the cure for social problems. J Med Ethics:medethics-2019-105981.

4 Horner C. Imagine a world... where ectogenesis isn't needed to eliminate social and economic barriers for women. J Med Ethics 2019.

5 Phillips A. The Politics of the Human. Cambridge, UK: Cambridge University Press, 2015.

6 Romanis EC. Partial Ectogenesis: freedom, equality and political perspective. J Med Ethics 2019.

7 Glenn Cohen I. Commentary on "Gestation, Equality and Freedom: Ectogenesis as a Political Perspective". J Med Ethics 2019

8 Cavaliere G. Gestation, equality and freedom: ectogenesis as a political perspective. J Med Ethics 2019:medethics-2019-105691-2019. 